Department of Internal Medicine (Prof. M. Matsuoka) and Department of Anatomy

(Prof. T. Fujita), Niigata University School of Medicine, Niigata, Japan

\title{
A Simple Micromethod of Preparing Peripheral Leukocytes and Platelets for Electron Microscopy
}

\author{
Akira HATTORI（服 部 晃）
}

Received July 25, 1970

The methodological advances of electron microscopy in hematology have not only added much new information concerning the physiology and pathology of blood cells, but also have made the techniques themselves for the fine-structural studies of blood easier than previously.

The general procedures for tissues, i.e., fixation, dehydration and embedding should be modified in the preparation of blood cells and other free cells. A variety of modifactory methods have thus been reported so far. ANDERSON $(1965,1966)$ recently reported a method for preparing peripheral leukocytes in which the cells in the buffy coat made by centrifugation of anticoagulated venous blood were prefixed in situ by superimposed glutaraldehyde in a glass tube. The buffy coat thus hardened was taken out as a disc from the tube and cut into small pieces to be treated thereafter as usual tissue blocks. This and similar methods (MiURA et al., 1966; Watanabe, Donahue and Hoggart, 1967; White, 1967) have been employed by an increasing number of investigators because of their simplicity and consistent results.

However, these methods originally need at least several milliliters of blood. This amount of blood from a normal subject is estimated to contain over ten million leukocytes and over one hundred million platelets. Considering that hundreds of the intended cells are surely enough for the observation if they are efficiently harvested and brought into the thin sections to be observed under the electron microscope, these methods may be said to be ineffective. Furthermore, several milliliters of blood, especially when taken recurrently, is not a small amount for younger anemic patients and for tiny animals.

On the other hand, methods using small amounts of blood (Chapman, 1962; Fedorko, 1967; Kondo and Takemura, 1965; Harven, Clarkson and Strife, 1967; Marikovsky and Danon, 1967) or cell suspension (Baker and Pearson, 1961; Malamed, 1963) have been reported or employed by a few investigators. Marikovsky and DANON(1967) reported a micromethod using polyethylene capillaries and phthalate ester mixture for the cell separation. FEDORKo (1967) used glass capillary tubes made for microhematocrit determination. These methods, however, either need special reagents and/or equipment, or seem to lack consistency.

\section{Materials and Methods}

Peripheral blood was obtained by either venous puncture or ear lobe puncture. For the examination of platelets in a circulating form it is necessary to obtain blood from vein using a siliconized system and to add an anticoagulant. For simplification 
of handling of small quantities of blood, plastic (polycarbonate) capillary tubes (Hematolon*) were employed. The polycarbonate tubes are made for microhematocrit determination and have the same outer dimension $(75 \mathrm{~mm}$ long, $1.7 \mathrm{~mm}$ outside diameter and $0.8 \mathrm{~mm}$ inside diameter) as the glass microhematocrit tubes. Since the inner surface of the tubes is previously heparinized, an anticoagulant is not needed for the examination of leukocytes

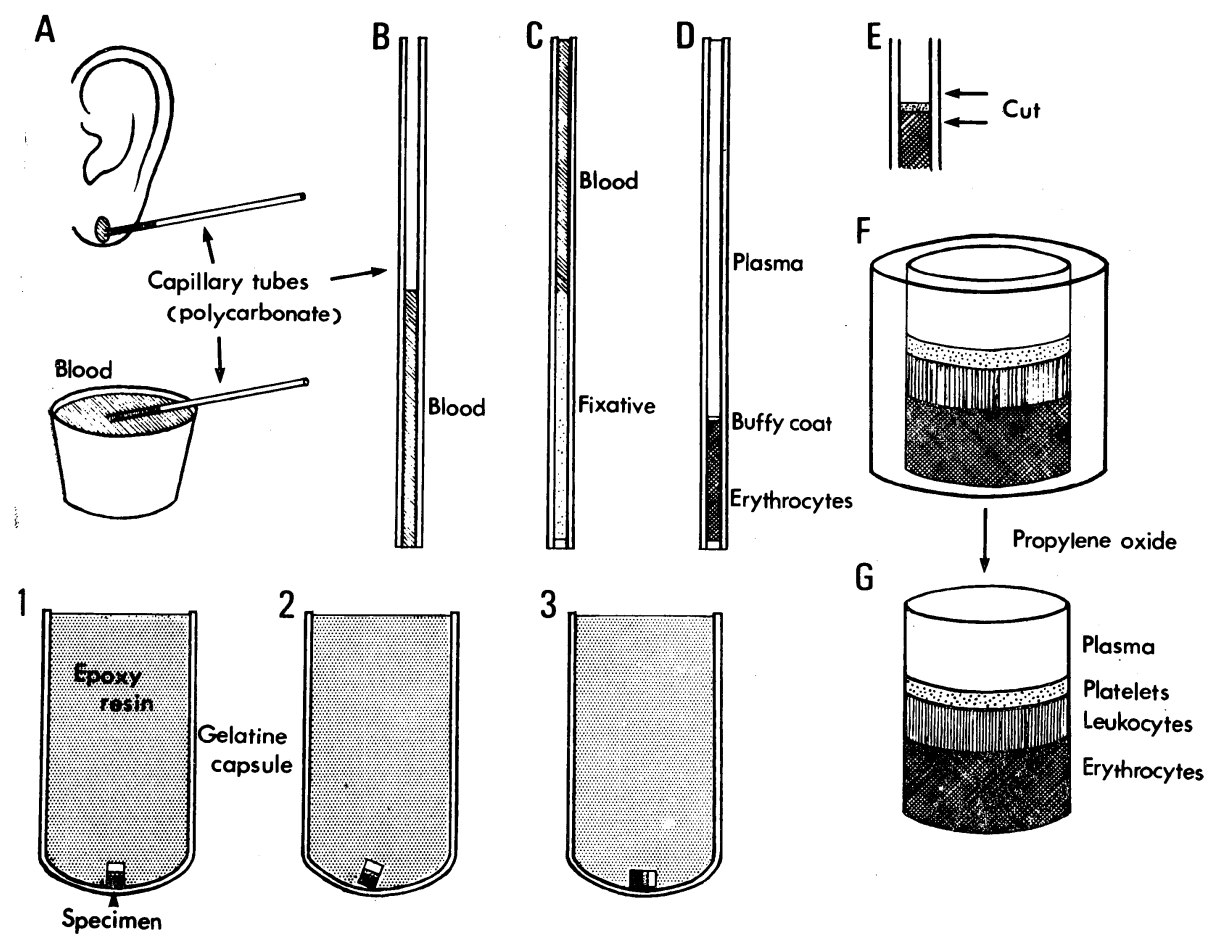

Fig. 1. Schematic representation of the described procedure $\mathbf{A}$ and B: Capillary or venous blood is sucked into polycarbonate capillary tubes up to the half height. C: The same volume of the fixative is sucked in and the bottom of the tube is sealed with Hemato-seal.* D: Gentle centrifugation produces a buffy coat between layers of erythrocytes and plasma. E: About $1 \mathrm{~mm}$ long segments containing the buffy coat are cut with a razor blade. $\mathbf{F}$ : The segment consisting of layers of erythrocytes, leukocytes, platelets and plasma is postfixed and dehydrated. G: The specimen freed from the plastic tube during treatment with propylene oxide is embedded in epoxy resin. 1-3: Three modes of settlement of specimens in the epon blocks.

Whole blood was sucked by capillarity into the tubes up to half their height by touching one end of the tubes on the blood (Fig. 1-A, B). A fixative, 0.5\% glutaraldehyde in $0.1 \mathrm{M}$ phosphate buffer adjusted at $\mathrm{pH} 7.4$ (various concentrations of glutaraldehyde were examined) was then sucked up into the tubes till the blood reached just below the upper end of the tubes (Fig. 1-C). The bottom of the tubes was sealed with Hemato-seal* (silicone rate $\times 30-50$ ). Thus over thirty samples

* Hematolon and Hemat-seal: Kayagaki Medico-Scientific Co. LTD. 3-14-16. Hongo, Bunkyo-ku, Tokyo, Japan. 
(tubes) could be prepared from $1 \mathrm{ml}$ of blood. Immediately the tubes were centrifuged at 1,000-2,000 r.p.m. for $5 \mathrm{~min}$ and then at 5,000 r.p.m. for $2-3 \mathrm{~min}$. The tubes now contained, from the bottom up, layers of erythrocytes, leukocytes, platelets and plasma (Fig. 1-D). They were left in a vertical position at room temperature for 30-60 min or more and the blood cells were fixed. With a fresh razor blade from each of these tubes a segment, $1 \mathrm{~mm}$ long, was cut out which contained the buffy coat (layers of leukocytes and platelets) and small portions of the erythrocyte layer and of supernatent plasma (Fig. 1-E, F). The segments were subsequently treated as usual tissue blocks. Fixation was continued in 4-5\% glutaraldehyde in $0.1 \mathrm{M}$ phosphate buffer for 2 hrs at room temperature. They were postfixed in $2 \%$ osmium tetroxide in the same buffer at $\mathrm{pH} 7.4$ for $2-4$ hrs at $4^{\circ} \mathrm{C}$, dehydrated by

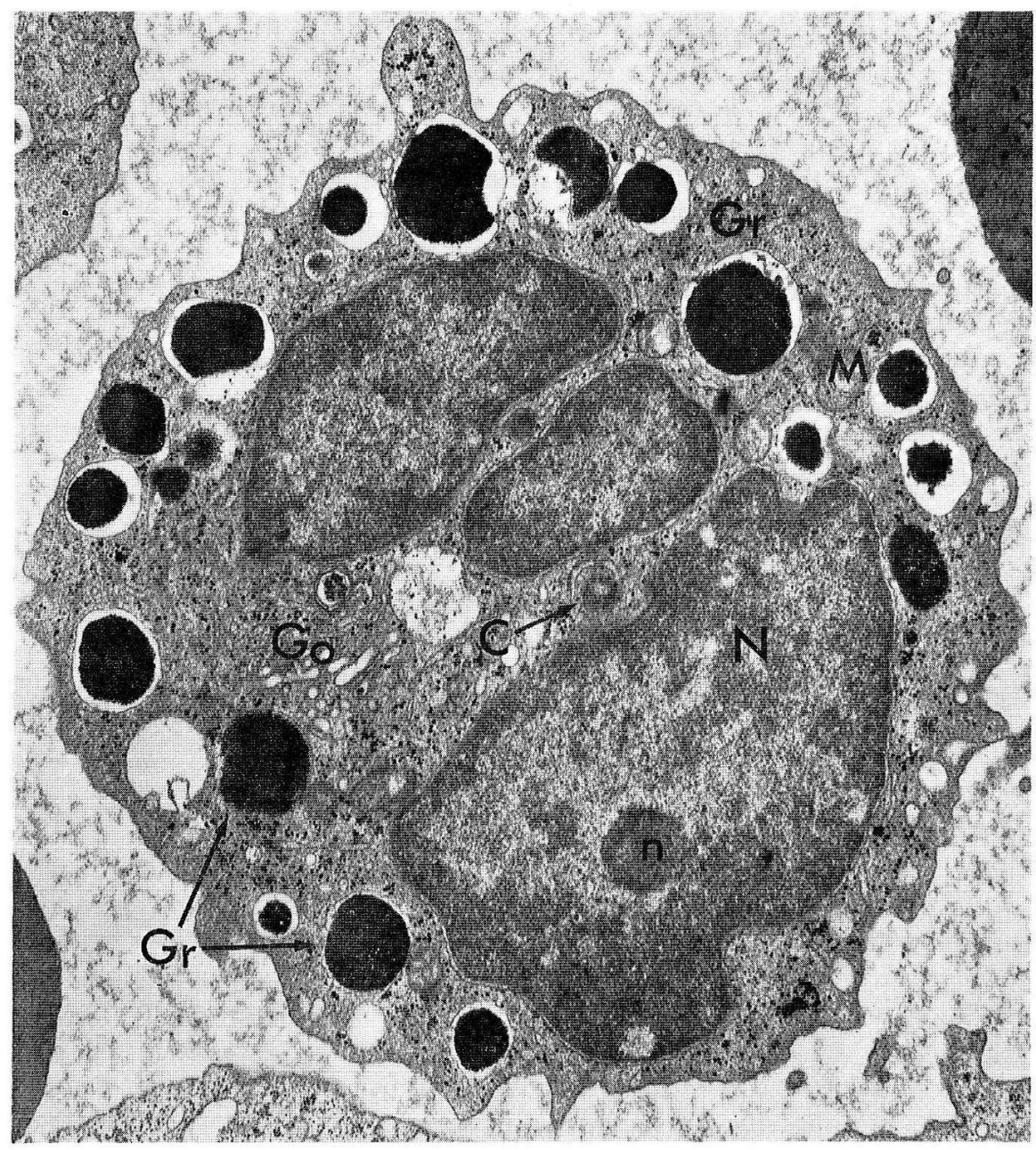

Fig. 2. A basophilic leukocyte in a patient with monocytic leukemia. Fixed by the described method. Thin sections were stained with uranil acetate and lead hydrate. $C$ centriole, Go Golgi apparatus, $G r$ basophilic granule, $M$ mitochondrion, $N$ nucleus, $n$ nucleolus. $\quad \times 11,000$ 
graded concentrations of ethanol and treated with propylene oxide for 15-20 min (7-10 changes). During this treatment with propylene oxide the wall of the segments made of polycarbonate were softened, swollen and gradually dissolved, and the specimens were exposed (Fig. 1-G). It is necessary to swirl rather vigorously the dehydration container at the addition of, and during the treatment with propylene oxide so that the softened plastic segments may not be stuck together and may be dissolved completely. After dehydration the specimens were embedded in epoxy resin (LuFT, 1961). Before the completion of the polymerization of resin, the specimens sank to the bottom of gelatine capsule as shown in Figure 1-1, -2 and -3 .

Most specimens were settled, probably on account of the difference in specific gravity of each cell layer, in a manner such that the erythrocyte layer was bottom most and the plasma layer upper most (Fig. 1-1, 2). After rough trimming under stereoscopic control, ultrathin sections were obtained using a Porter-Blum microtome equipped with glass knives The erythrocytes first appeared in the sections followed by leukocytes, platelets and supernatent plasma layer in that order. For the confirmation of the cell types in the sections, thick sections were cut at appropriate intervals and stained with toluidine blue (ҮАмамото, 1963) to examine light microscopically till the intended type of cells appeared. This procedure of confirmation could be usually omitted because the intended cell layer was easily distinguished under stereoscope by the difference in the intensity of brownish color induced by osmification: the erythrocyte layer was brownish black, leukocyte layer, brown and platelet layer, light brown and the plasma was palest.

In sectioning of the few blocks in which specimens were laid as shown in Figure 1-3 the confirmation procedure was not needed because their sections always contained all layers of the cells.

Thin sections were stained with lead hydrate (Millonig, 1961) and uranyl acetate, and examined in a Hitachi HS-7S electron microscope.

\section{Results and Comments}

As capillary tubes made of glass or plastic are used for microhematocrit determination in many hospitals and laboratories in the world, the present method using this type of tubes may be readily examined and employed.

Sucking of the fixative into the capillary tubes must be done slowly. If not, rapidly flowing-in fixative is mixed with the blood and may cause poor separation of cells.

For the first fixative, various concentrations $(6,5,4,3,2,1.5,1,0.75,0.6,0.5,0.4$, $0.25,0.125 \%)$ of glutaraldehyde were examined. Higher concentrations of glutaraldehyde solidified plasma in a relatively short time and made cell separation impossible or incomplete. Lower concentrations were proved inadequate for the preservation of cell structures. About $0.5 \%$ of glutaraldehyde was found to bring about both clear cell separation and good fixation. Omitting the use of the first fixative produced superior cell separation but inferior cell fine structure preservation.

The plastic tubes did not become deformed to the naked eyes while being cut, since the wall has adequate thickness and consistency.

The buffy coat (leukocyte and platelet rich layer) is about $0.3-0.5 \mathrm{~mm}$ thick in the subjects whose leukocyte and platelet counts are within the normal range. This 
thickness of the buffy coat is enough for trimming under stereoscopic control. When the leukocyte or platelet count is extremely elevated as in cases of chronic leukemia and thrombocythemia, the layer may be thickened as much as $2-3 \mathrm{~mm}$. Two or even more specimens full of leukocytes or platelets can be obtained from one capillary in these cases. On the contrary, in leukopenic or thrombocytopenic patients or animals, the thickness of the layer may sometimes be not enough. Then it is preferable to obtain samples from leukocyte and platelet rich plasma separated by a gentle centrifugation (about 500 r.p.m. for $10 \mathrm{~min}$ ) from 1-2 $\mathrm{ml}$ of citrated whole blood.

The present method fixes plasma at less than half of its natural concentration. In final electron micrographs, as a results, the background (plasma) of the cells, which is rather dark and makes the cells indistinct when plasma is fixed as a whole by glutaraldehyde, appears lighter causing an adequate contrast to the cells.

The polycarbonate is gradually dissolved in propylene oxide. Thus the release of the specimen from the capillary segment is achieved simply and without exposing the cells to direct handling. In the micromethod developed by MARIKOVSKY and DANON (1967) this procedure consists of expelling cell agglomerate from the capillary segment (polyethylene which is not dissolved in propylene oxide) using a thin wire in $70 \%$ ethanol or acetone. The present method seems to have an advantage over their method in simplicity and minimization of cell damage in the separation of the content from the tube. FEDORKO (1967) used glass capillaries, which he broke above the buffy coat layer after centrifugation and then expressed the layer into fixative. His method seems, though simple, to lack consistency.

Separation of the cells in the present method is inferior to that in the method developed by MARIKovsky and DANON (1967) in which a series of phthalate ester mixtures of differential specific gravity is used for this purpose, and it may be also inferior to that of ANDERSON in which whole blood is centrifuged without dilution. However, as for general use, a strict separation of cells does not seem essential. If one wants it in the present method, one may effectively add dextran of low molecular weight to the first fixative to a final concentration of $0.25-0.5 \%$.

Blood cells fixed with the present method have their fine structure well preserved. Figure 2 shows a basophilic leukocyte for example. It contains several round granules surrounded by a limiting membrane. Their contents consist of two kinds of dense particles, i.e., smaller and larger ones. These findings are in good accordance with the excellent descriptions by ANDERson (1966) and WATANABE, DonaHuE and HogGart (1967).

Finally, though the present method is considered to be especially useful for the recurrent examination of anemic patients (children and infants) and small animals, this is not limited to the peripheral blood, but is surely adoptable, with some modifications or without, for the study of small quantities of free cells such as cultured cells and those in the bone marrow aspirate and pleural, peritoneal and spinal fluid as well as subcellular fractions such as mitochondria and nuclei.

\section{Summary}

For the electron microscopic examination of peripheral leukocytes and platelets from a small amount of whole blood, a simple method has been proposed by a 
modification of the technique of ANDERSON (1966).

Simple handling of this method is accomplished by employment of plastic (polycarbonate) capillary tubes for microhematocrit determination. This type of tube is gradually dissolved during treatment with propylene oxide and not only simplifies the procedures, but also minimizes the cell damage.

Venous or capillary blood was sucked into the tubes up to the half height and then an equal volume of $0.5 \%$ glutaraldehyde (in $0.1 \mathrm{M}$ phosphate buffer) was sucked in. After being sealed, the tubes were centrifuged and $1 \mathrm{~mm}$ long segments containing the buffy coat were cut from the tubes. They were postfixed and dehydrated as usual tissue blocks. The specimens freed from the tubes which dissolved during treatment with propylene oxide were embedded in epoxy resin.

This method well preserves the fine structure of blood cells and is recommended for clinical use especially in the examination on anemic and juvenile patients and for experiments on small animals.

Acknowledgements. The author would like to express his sincere thanks to Prof. Matsuzo Matsuoka for his direction and kind encouragement and to Prof. Tsuneo Fujita and Assoc. Prof. Masayuki Mryoshi for their criticism and advice in the preparation of this paper.

\section{白血球と血小板の電顕観察のための簡便な微量法}

(内容自抄)

プロピレンオキサイドに融けるプラスチック（polycarbonate）製毛細管（微少へマト クリット用，市販）を利用して，少量の血液から白血球と血小板を電顕観察する簡便な 方法（ナンダ・ソン変法）を報告した。

耳垂またほ静脈から血液を ペリン処理した毛細管の半分まで吸い上げ, 次に等量の $0.5 \%$ グルタール アルデヒド $(0.1 \mathrm{M}$ 燐酸緩衝液, $\mathrm{pH} 7.4)$ を吸い上げる. $1 \mathrm{ml}$ の血 液から30個以上の試料を作ることが出来る.下端を閉じ遠沈 $(1,000 \sim 2,000$ 回転 5 分, 次に 5,000 回転 $2 \sim 3$ 分). 白血球, 血小板定含む バッフィ ユート部分 $(1 \mathrm{~mm})$ を切り出 して後固定, 脱水する. プロピレンオキサイド中で遊離した試料它エポン樹脂に包理. 本法による血球の微細構造の保存は，こ机までの方法にくらべて遜色ない，本法は貧血 者や幼小児, 小動物の検查にとくにす寸められ, また 他の遊離細胞や細胞小器官の遠 心分画なぞの観察に応用できる.

\section{References}

Anderson, D. R.: A method of preparing peripheral leukocytes for electron microscopy. J. Ultrastr. Res. 13: 263-268 (1965).

: Ultrastructure of normal and leukemic leukocytes in human peripheral blood. J. Ultrastr. Res. Suppl. 9 (1966).

Baker, R. F. and H. E. Pearson: New embedding method for cell suspensions. J. biophys. biochem. Cytol. 9: 217-218 (1961).

Chapman, A. L.: Preparation of small quantities of blood leukocytes for electron microscopy. Stain Technol. 37: 387-388 (1962).

Fedorko, M.: Effect of chloroquine on morphology of cytoplasmic granules in maturing leukocytes 
-an ultrastructural study. J. clin. Invest. 46: 1932-1942 (1967).

Harven, E. de, B. Clarkson and A. Strife: Electron microscopic study of human leukemic cells in tissue culture. Cancer 20: 911-925 (1967).

Kondo, $\mathbf{K}$. and $\mathbf{K}$. Takemura: Application of epoxy resin embedding method for free cells. J. Electron Microsc. (Tokyo) 14: 50-51 (1965).

Luft, J. H.: Improvement in epoxy resin embedding methods. J. biophys. biochem. Cytol. 9: 409414 (1961).

Malamed, S.: Use of a microcentrifuge for preparation of isolated mitochondria and cell suspensions for electron microscopy. J. Cell Biol. 18: 696-700 (1963).

Marikovsky, Y. and D. Danon: A micromethod for fixation and embedding of separated blood cell fraction for electron microscopy. J. Ultrastr. Res. 18: 176-180 (1967).

Millonig, G.: A modified procedure for lead staining of thin sections. J. biophys. biochem. Cytol. 11: 736 (1961).

Miura, A., A. Shibata, S. Takase, K. Onodera, K. Suzuki, S. Sakamoto, A. Yamagata and N. Takahashi: A method of preparing peripheral leukocytes for electron microscopy (abstract in Japanese). Acta haematol. jap. 29: 794 (1966).

Watanabe, I., S. Donahue and N. Hoggart: Method for electron microscopic studies of circulating human leukocytes and observations on their fine structure. J. Ultrastr. Res. 20: 366-382 (1967).

White, J. G.: A simple method for preservation of fine structure in blood cells. Thrombos. Diathes. haemorrh. 18: 745-753 (1967).

Yamamoto, T.: A method of toluidine blue stain for epoxy embedded tissues for light microscopy. Acta anat. nippon. 38: 124-128 (1963).

服 部晃

厂951 新潟市旭町 1

新潟大学医学部

第一内科学教室
Dr. Akira Hattori

Department of Internal Medicine Niigata University School of Medicine 951 Niigata, Japan 